\title{
Native mRNA antisense-accessible sites library for the selection of antisense oligonucleotides, PNAs, and siRNAs
}

HUAFENG FANG, YUEFEI SHEN, and JOHN-STEPHEN TAYLOR

Department of Chemistry, Washington University, St. Louis, Missouri 63130, USA

\begin{abstract}
A procedure for rapidly generating a library of antisense-accessible sites on native mRNAs (mRNA antisense-accessible sites library [MASL]) is described that involves reverse transcription of whole cell mRNA extracts with a random oligodeoxynucleotide primer followed by mRNA-specific polymerase chain reaction (PCR). Antisense phosphorothioate oligodeoxynucleotides (ODNs), peptide nucleic acids (PNAs), and small interfering RNAs (siRNAs) can then be identified by screening against the antisense-accessible sites. The utility of this methodology is demonstrated for the identification of more effective inhibitors of inducible nitric oxide synthase (iNOS) induction than have previously been reported. This method may also be useful for constraining folding calculations of native mRNAs and for designing mRNA imaging probes.
\end{abstract}

Keywords: native mRNA; antisense; siRNA; PNA; iNOS

\section{INTRODUCTION}

Antisense oligodeoxynucleotides (ODNs), peptide nucleic acids (PNAs), and small interfering RNAs (siRNAs) are powerful tools for the life sciences because of their ability to selectively down-regulate gene expression, and they have been widely used to determine gene function and to validate drug targets and pathways. The biological activity of these agents is site dependent and is thought to be modulated by the structure and folding of the target R. A study showing a similarity between the site-dependent biological activities of phosphorothioate antisense ODNs and siRNAs (Kretschmer-Kazemi Far and Sczakiel 2003) suggested that their respective activity depends on the accessibility of the mRNA site, which would be affected by folding. A more recent study has reached a conclusion concerning target site accessibility and the effectiveness of both siRNAs and microRNAs (miRNAs) (Obernosterer et al. 2008). Likewise, antisense target accessibility should also be important for the effectiveness of fluorescent probes such as molecular beacons and positron emission tomography (PET) imaging agents (Rodriguez et al. 2007; Mukherjee et al. 2009), as

Reprint requests to: John-Stephen Taylor, Department of Chemistry, Washington University, One Brookings Drive, St. Louis, MO 63130 USA; e-mail: taylor@wustl.edu; fax: (314) 935-4481.

Article published online ahead of print. Article and publication date are at http://www.rnajournal.org/cgi/doi/10.1261/rna.1940610. well as for determining the folding of native mRNA (Chen 2008).

Several experimental methods for mapping accessible sites on mRNA have been developed in recent years, including RNase H mapping (Ho et al. 1996, 1998) oligonucleotide arrays (Sun et al. 2006), reverse transcription with random oligodeoxynucleotide libraries (RT-ROL) (Allawi et al. 2001), mRNA accessible site tagging (MAST) (Zhang et al. 2003), and serial analysis of antisense binding sites (SAABS) (Fang et al. 2005). These methods have resulted in the identification of ODN sequences exhibiting high affinity and selectivity for the target mRNA in vitro, some of which are also effective antisense reagents in vivo. To date, all these methods have utilized RNA substrates produced by in vitro transcription of cDNA clones, which result in nonnative mRNAs that lack the endogenous capping sequence and the poly $(\mathrm{A})$ tail. The RNAs produced in this way are also often truncated and contain parts of sequences arising from the transcription vector, and therefore may not fold in the same way as native mRNAs. Furthermore, making or acquiring the cDNAs is time-consuming and costly, and may not result in the identification of the native RNA target sites. To circumvent these problems, we report a method for generating a library of antisense-accessible sites on native mRNA transcripts extracted directly from cells (mRNA antisense-accessible sites library [MASL]), which can be used to select active antisense and siRNA agents. 

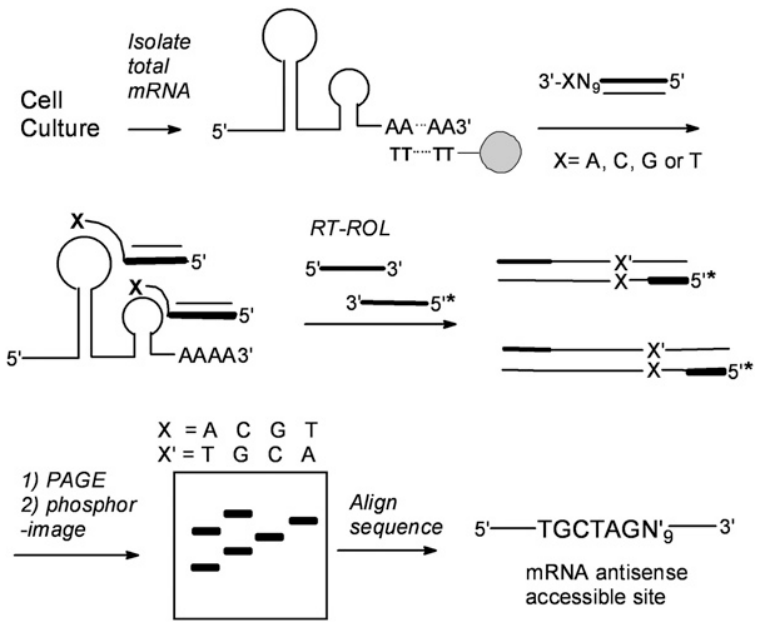

FIGURE 1. Schematic diagram for the construction of a native mRNA antisense-accessible sites library (MASL) using a modified reverse transcriptase random oligodeoxynucleotide (RT-ROL) assay. A random 9-mer oligodeoxynucleotide library terminating in a specific base $\mathrm{X}$ on the $3^{\prime}$-end and a PCR tag on the $5^{\prime}$-end is prehybridized with an ODN complementary to the tag sequence and then allowed to hybridize with total mRNA extracted from the target cells. The cDNA is then amplified by target mRNA-specific forward PCR primers and a reverse primer consisting of the PCR tag and the products electrophoresed on a denaturing gel. Comparison of the observed bands to the mRNA sequence enables identification of the antisense-accessible sites.

To construct the library of antisense-accessible sites, we required a method that could map antisense-accessible sites on a full-length native mRNA target, in the presence of nontarget mRNAs. This requirement ruled out the use of oligonucleotide arrays and RNase $\mathrm{H}$ mapping techniques, and it directed us to the RT-ROL method (Allawi et al. 2001). This method makes use of a library of random oligodeoxynucleotides attached to a polymerase chain reaction (PCR) tag to prime cDNA synthesis by reverse transcriptase from primer accessible sites on the mRNA. This step is then followed by PCR amplification with primers corresponding to the PCR tag and to different sites along the target mRNA. The resulting PCR products can then be assigned to specific sequences of the mRNA based on their size, and from this assignment, the primer binding sites can be deduced.

In the originally reported method (Allawi et al. 2001), the primer was a completely random sequence, making it difficult to assign the PCR product bands to a specific site on the mRNA because of the difficulty in determining the precise size of the PCR product. We later improved the precision of this method, utilizing a set of four separate random primer libraries terminating in either $A, C, G$, or T; thereby making it much easier to assign the PCR product bands to specific sequences by the pattern of bands produced (Fang et al. 2005). Because amplification of the reverse transcripts utilizes primers specific to the target mRNA, the RT-ROL procedure can be carried out in whole cell RNA extracts (Fig. 1).

\section{RESULTS AND DISCUSSION}

To illustrate our method, we generated a native mRNA antisense-accessible library for inducible nitric oxide synthase (iNOS) expressed in a mouse macrophage cell line. Total mRNA was obtained from LPS-activated RAW264.7 cells using a monophasic phenol guanidine isothiocyanate solution, followed by magnetic separation of mRNA hybridized to biotinylated oligo(dT) with streptavidin-coated paramagnetic particles. The total mRNA was first heated for $5 \mathrm{~min}$ at $65^{\circ} \mathrm{C}$ in the presence of dNTPs, followed by slowly cooling to room temperature, and was incubated for another $30 \mathrm{~min}$ in buffer to refold the mRNA. The random ODN library Tag- $\mathrm{N}_{9} \mathrm{X}, \mathrm{d}$ (GGATTTGCTGGTGCAGTACA NNNNNNNNNX), where $\mathrm{X}$ is $\mathrm{A}, \mathrm{T}, \mathrm{G}$, or $\mathrm{C}$, was first annealed to tag', the sequence complementary to tag, to prevent unwanted hybridization to the mRNAs, and was then incubated with the total mRNA in the presence of the RNase inhibitor. After $30 \mathrm{~min}$, SuperScript II reverse transcriptase was added and incubated for another $5 \mathrm{~min}$ at room temperature. The reaction was then incubated for $50 \mathrm{~min}$ at $42^{\circ} \mathrm{C}$ and was inactivated by heating for $15 \mathrm{~min}$ at $70^{\circ} \mathrm{C}$.

To identify the mRNA accessible sites, PCR was carried out with $5^{\prime}{ }^{32} \mathrm{P}$-end-labeled 20-mer PCR Tag d(GGATTTG CTGGTGCAGTACA) as the reverse primer and a set of 26 forward PCR primers matching different sites along the mouse iNOS mRNA (Supplemental Table 1). PCR was

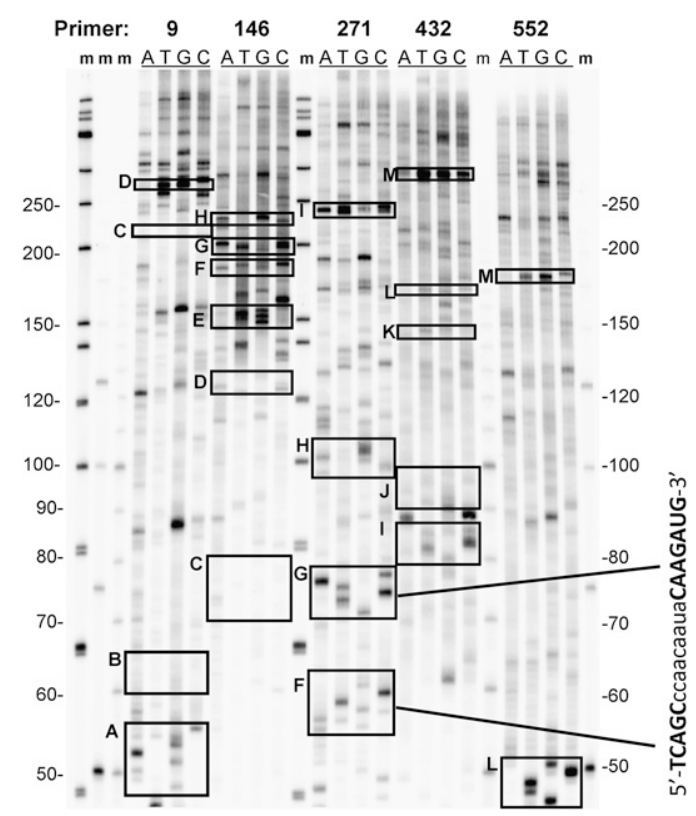

FIGURE 2. Mapping antisense-accessible sites on native mouse iNOS mRNA. Phosphorimage of polyacrylamide gels of PCR products from the RT-ROL assay for five sections of the iNOS mRNA using primers 9, 146, 271, 432, and 552. Markers: $\Phi 174$ digest, 25-bp DNA ladder, and a 10-bp DNA ladder. The lane headings refer to X in the X-N9Tag primer. 


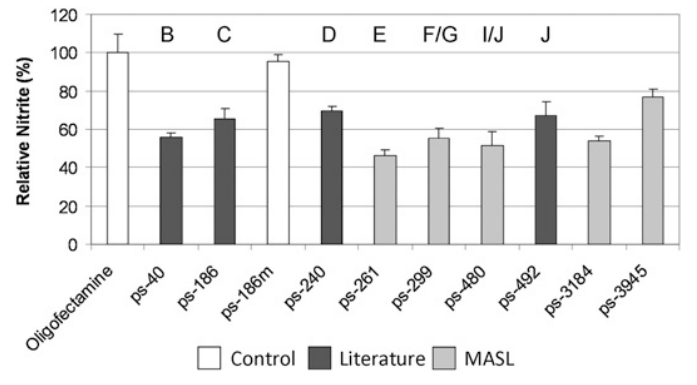

FIGURE 3. Inhibition of iNOS expression by phosphorothioate oligodeoxynucleotides (ps-ODNs). Mouse RAW264.7 cells were transfected with $0.5 \mu \mathrm{M}$ ps-ODN/Oligofectamine and $6 \mathrm{~h}$ later were induced by LPS and IFN- $\gamma$. After an additional $18 \mathrm{~h}$, the supernatant was collected and the relative percentage of nitrite determined by the Griess assay. Letters refer to the corresponding target sites in Figures 2 and 6. A slash between letters indicates overlap between sites.

carried out with GoTaq polymerase and the products electrophoresed on $8 \%$ denaturing polyacrylamide gels. The accessible site can then be determined relative to the position of the forward primer from the length of the PCR band, which corresponds to the length from the $5^{\prime}$-end of the forward primer to the $3^{\prime}$-end of the random primer plus 29 nucleotides (nt) (the sum of nine random nucleotides plus the 20-mer PCR tag).

The PCR primers were designed to minimize falsepositive results from the PCR step in two ways. The first way was to use four random primers terminating in either $\mathrm{A}, \mathrm{T}, \mathrm{G}$, or $\mathrm{C}$, which can only prime if the terminal nucleotide is complementary to the accessible nucleotide in the mRNA. Thus, the pattern of PCR bands produced by these four primers must match the mRNA sequence to be a valid accessible site. The second way was to use PCR primers for every $\sim 150 \mathrm{nt}$ so that the band pattern resulting from a primed site could be easily resolved on an $8 \%$ polyacrylamide gel electrophoresis (PAGE) gel. In addition, the assignment of the bands to a primed site can be corroborated by the presence of the same pattern of bands in the PCR products produced from the next PCR primer. For example, in Figure 2 we observe a pattern of bands (Fig. 2, site F) at $\sim 60$ base pairs (bp) and at $\sim 75 \mathrm{bp}$ (Fig. 2, site G) when using the 271 primer that can be easily matched to the mRNA sequence. The same pattern is also observed in the PCR reaction with primer 146 at $\sim 185 \mathrm{bp}$ (Fig. 2, site F) and at $\sim 200$ bp (Fig. 2, site G), although they cannot be accurately read. Sometimes the bands appear to be doubled (as in Fig. 2, site F, with the 271 primer), possibly due to incomplete denaturation or to a PCR synthesis error. Bands arising from experimental artifacts can be identified by comparing gels from multiple RT-ROL experiments.

We were able to map about 10 readily identifiable and corroborated antisense-accessible sites on the native iNOS mRNA using 26 forward primers that covered the entire mRNA sequence. To determine which of our sites corre- sponded to good antisense and siRNA sites, we synthesized 10 phosphorothioate oligodeoxynucleotides (ps-ODNs), six siRNAs, and four PNAs (Tables 1-3). The ps-ODNs were made to be directly complementary to the mapped antisense sites, but the siRNA agents were shifted to conform with the rules established for optimal siRNA agents with the $3^{\prime}$-terminal UU complementary to an AA on the mRNA template (Ambion; www.ambion.com/techlib/misc/siRNA finder.html).

The activity of the ps-ODNs and siRNAs were determined in mouse peritoneal macrophage RAW264.7 cells (ATCC TIB-71) in comparison with previously reported agents (Tables 1,2$)$. Cells were transfected with a $0.5 \mu \mathrm{M}$ ps-ODN Oligofectamine complex or a $100 \mathrm{nM}$ siRNA Lipofectamine 2000 complex in the absence of serum for $6 \mathrm{~h}$, after which $10 \%$ fetal bovine serum (FBS) was added and the cells were activated with LPS and IFN- $\gamma$. Twentyfour hours later, the amount of nitrite present in a portion of the supernatant $(50 \mu \mathrm{L})$ was quantified with the Griess reagent by an absorbance at $540 \mathrm{~nm}$. The cells were then harvested for real-time PCR analysis of iNOS mRNA. The MASL-derived antisense ps-ODNs-ps-260, ps-299, ps480, and ps-3184-were as good or better at inhibiting nitric oxide (NO) production than the previously reported antisense agents ps-40 (Grasso et al. 2003), start codon targeted ps-186 (Flesch et al. 1994; Arima et al. 1997; Bilecki et al. 1997), ps-240 (Chiarantini et al. 2002), and ps492 (Flesch et al. 1994), and all were much better than the mismatched ps-186m and transfection reagent control (Fig. $3)$. The previously reported ps-40 and ps-186 antisense ODNs corresponded to MASL sites B and C, respectively, which showed very weak to nonexistent bands in the RTROL assay, indicating that they are not very accessible (Fig. 2). The previously reported ps-240 (Fig. 3, site D) and ps492 (Fig. 3, site J) antisense ODN target sites preceding or following MASL sites E and I, which could also explain why

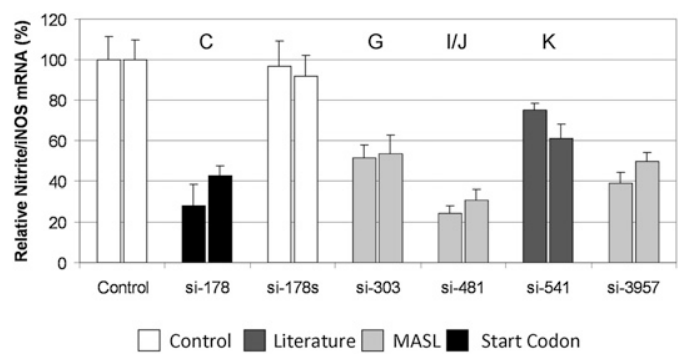

FIGURE 4. Inhibition of iNOS expression by siRNAs. Mouse RAW264.7 cells were transfected with $100 \mathrm{nM}$ siRNA/1.67 $\mu \mathrm{g} / \mathrm{mL}$ Lipofectamine 2000 and $6 \mathrm{~h}$ later were induced by LPS and IFN- $\gamma$. After an additional $18 \mathrm{~h}$, the supernatant was collected for the Griess assay of the relative percentage of nitrite (left bar), and cells were harvested for real-time PCR analysis of the iNOS mRNA (right bar). Letters refer to the corresponding target site in the MASL gel in Figures 2 and 6. A slash between letters indicates overlap between sites. 


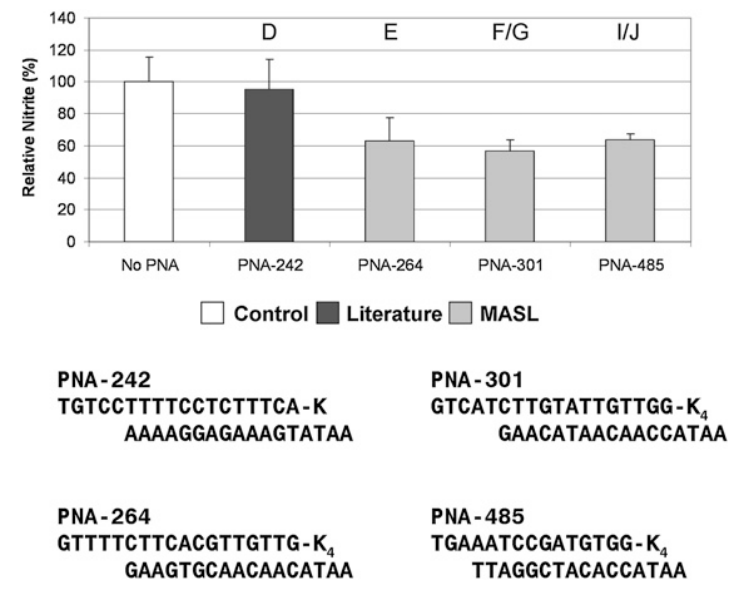

FIGURE 5. Inhibition of iNOS expression by PNAs. Mouse RAW264.7 cells were transfected with $100 \mathrm{nM}$ PNA•ODN of the hybrid shown (top, PNA; bottom, ODN) and $1.67 \mu \mathrm{g} / \mu \mathrm{L}$ Lipofectamine 2000, and $6 \mathrm{~h}$ later iNOS expression was induced by LPS and IFN- $\gamma$. After an additional $18 \mathrm{~h}$, the supernatant was collected for the Griess assay of the relative percentage of nitrite. Letters refer to the corresponding target site in the MASL gel in Figures 2 and 6. A slash between letters indicates overlap between sites.

ps-ODNs targeted to these sites, were better inhibitors than ps-40 and ps- 186 .

Inhibition of NO production with the MASL-derived siRNAs si-303 (Fig. 3, site F/G, 49\%), si-481 (Fig. 3, site I/J, $76 \%)$, and si-3957 (61\%) was much better than for the previously reported si-541 (Fig. 4, site K, 25\%; Beeharry et al. 2004). The Griess assay results were also confirmed by real-time PCR of iNOS mRNA (Fig. 4, left and right bars). It is hard to assess the accessibility of site $\mathrm{K}$ because while it appears to be as weak as site $\mathrm{L}$ when probed by primer 432 , site $\mathrm{L}$ appears to be quite strong when mapped by primer 552 (Fig. 2). Unfortunately, site $\mathrm{K}$ cannot be compared with site L by primer 552 because it precedes the position of the primer (see Fig. 6 below). It is clear, however, that the high efficiency of the si-178, which targets the start codon site (C), cannot be explained by accessibility alone, since site $\mathrm{C}$ was not identified as an MASL site (Fig. 4).

PNAs directed to a subset of sites were also investigated for their ability to inhibit iNOS expression (Fig. 5; Table 3). To transfect the RAW264.7 cells, the PNAs were hybridized to partially complementary ODNs to render them negatively charged so that they could be transfected with the cationic liposome forming Lipofectamine 2000 (Nastruzzi et al. 2000; Braasch and Corey 2001, 2002), as were the siRNAs. We obtained the least inhibition with PNA-242 (about 6\%) that targets site $\mathrm{D}$, but much better inhibition with PNA-264, PNA-301, and PNA-485 (37\%, 43\%, and $36 \%$, respectively) targeting sites E, F/G, and I/J. PNA-242 corresponds closely to PNA Lys-CCTTTTCCTCTTTC-Gly (Giovine et al. 1998; Chiarantini et al. 2005), which has previously been reported to cause at best $40 \%$ inhibition of iNOS expression in murine macrophages when exposed to PNA-loaded red blood cells (Chiarantini et al. 2002). Again, the lower activity of PNA-242 could be attributed to lower accessibility of this site compared with the others, as indicated by the much weaker bands in the MASL gel (Fig. 2).

Most of the ps-ODNs, PNAs, or siRNAs derived from the native iNOS mRNA antisense-accessible sites library were effective in inhibiting induction of iNOS expression in the RAW264.7 cell line, and most were as good or better than the previously reported counterparts. The slightly weaker performance of the previously reported ps-ODN antisense agents may be explained by the fact that they targeted sites that were only adjacent to, or partially overlapping, those sites identified by MASL (Fig. 6). Likewise, all of the MASL PNAs were found to be superior to the previously reported PNA-242, which was not identified as a strong MASL site, and this again emphasizes the importance of accessibility. Although a very effective siRNA was found by MASL, it is harder to establish a strong

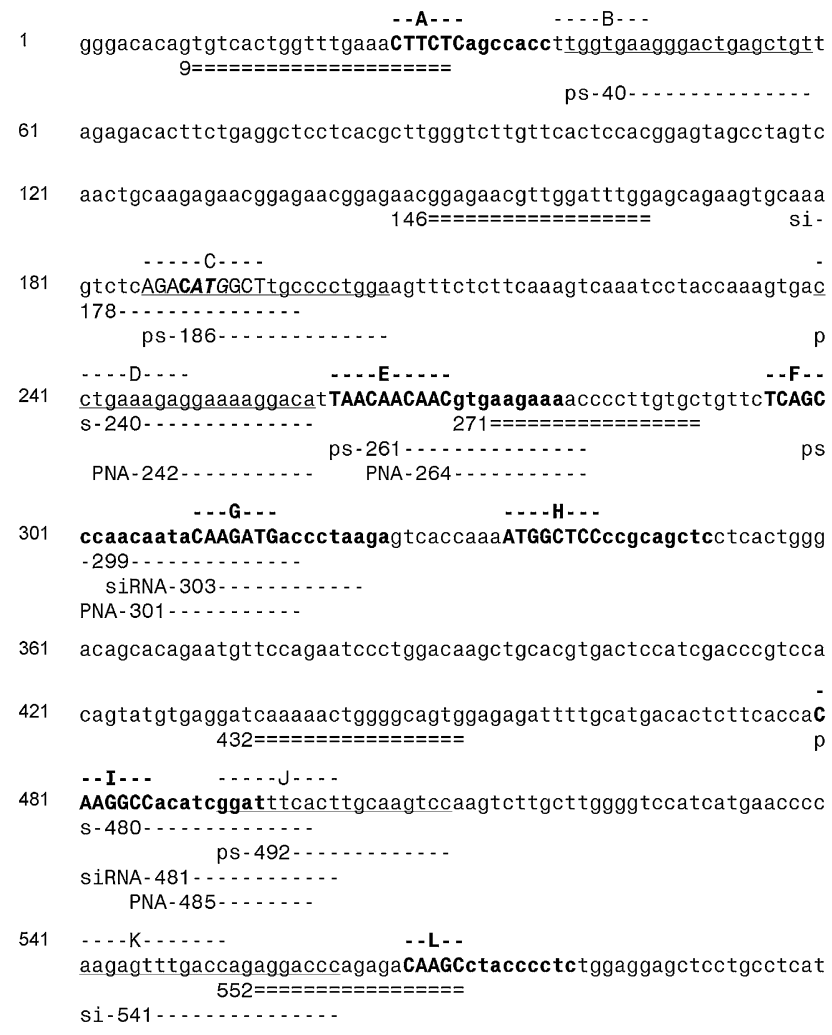

FIGURE 6. Native mRNA antisense-accessible sites from MASL (bold) in comparison with sites for previously reported antisenseand siRNA-targeted sequences (underlined). Uppercase bases represent the position of the primer terminus that generated (or would have generated in the case of previous agents) an observable band in the RT-ROL assay, and bold lowercase bases correspond to the corresponding binding sites of the random 9-mer section of the primer. Forward PCR primers are indicated below the sequence with a double dashed line, and the ps-DNAs, si-RNAs, and PNAs are indicated with a single dashed line. The start codon (190) is in uppercase bold italic. 
TABLE 1. Phosphorothioate modified antisense oligodeoxynucleotides for inhibition of iNOS expression

\begin{tabular}{|c|c|c|c|}
\hline ps-ODN & Site & Sequence & Source \\
\hline ps-40 & B & ACAGСТСАGTСССТTСАССА & Grasso et al. (2003) \\
\hline ps-186 & $\mathrm{C}$ & TCCAGGGGCAAGCCATGTCT & $\begin{array}{l}\text { Flesch et al. (1994); Arima et al } \\
\text { (1997); Bilecki et al. (1997) }\end{array}$ \\
\hline ps-186m & & TCCTGGGGCAAACCAGGTCT & ps-186 3-nt mismatch \\
\hline ps-240 & $\mathrm{D}$ & TGTCСTTTTCСТCTTTCAGG & Chiarantini et al. (2002) \\
\hline ps-261 & $\mathrm{E}$ & GTTTTCTTCACGTTGTTGTTA & MASL \\
\hline ps-299 & F/G & GTCATCTTGTATTGTTGGGC & MASL \\
\hline ps-480 & 1 & TGAAATCCGATGTGGCCTTG & MASL \\
\hline ps-492 & J & GGACTTGCAAGTGAAATCC & Flesch et al. (1994) \\
\hline ps-3184 & & ATGCGGCСTCCTTTGAGCCC & MASL \\
\hline ps-3945 & & CTAAGTATTAGAGCGGTGGCA & MASL \\
\hline
\end{tabular}

1.5:1.25:1.15:1.0 (A:C:G:T). All ODNs were purified by $15 \%$ or $20 \%$ denaturing PAGE before and after any ${ }^{32} \mathrm{P}$-ATP radiolabeling. The PNA-Lys conjugates were synthesized on a $2 \mu \mathrm{mol}$ scale on an XAL-PEG-PS resin by standard solid-phase Fmoc chemistry on an Expedite 8909 Synthesizer (Applied Biosystems) and purified by reverse phase chromatography on a Microsorb-MV 300-5 C-18 column by previously described methods. PNA $\bullet$ ODN hybrids were prepared by heating for $10 \mathrm{~min}$ at $80^{\circ} \mathrm{C}$, followed by cooling to room temperature over an hour. The Silencer siRNA Construction Kit (Applied Biosystems/Ambion) was used to synthesize the siRNA in vitro following the manufacturer's instructions. correlation with accessibility since the start codon targeting siRNA was also very effective yet it did not correspond to a readily identifiable MASL site. It may be that other factors in addition to accessibility are important in the mechanism of siRNA inhibition.

We have shown that the native mRNA antisense-accessible sites library described in this work can be used for the selection of highly effective antisense ps-ODNs, PNAs, and siRNAs. This library may also be useful for developing antisense-based mRNA imaging agents (Rodriguez et al. 2007; Mukherjee et al. 2009) and for constraining secondary structure predictions of native mRNAs (Chen 2008). Other factors, such as protein interactions and binding, may affect folding and accessibility of sites on mRNA in vivo and may explain variations in the effectiveness of the ps-ODN, PNA, and siRNA agents with sequence. To better deal with these factors, we are currently developing methods for mapping the antisense-accessible sites directly within cells.

\section{Native mRNA isolation}

Total RNA was extracted from RAW264.7 for a model using TRIzol Reagent (Invitrogen), a monophasic phenol guanidine isothiocyanate solution, following the manufacturer's instructions. Isolation and purification of mRNA was performed with the PolyATract mRNA Isolation System (Promega Life Science), which involves magnetic separation of mRNA hybridized to biotinylated oligo(dT) with streptavidin-coated paramagnetic particles, following the manufacturer's instructions.

\section{Modified RT-ROL antisense-accessible sites mapping}

The ODN library used for mapping the antisense binding sites on the mRNA by the modified RT-ROL assay is shown in Supplemental Table 1 . The total mRNA was heated for $5 \mathrm{~min}$ to $65^{\circ} \mathrm{C}$ in the presence of $1 \mathrm{mM}$ dNTPs, followed by slowly cooling to room temperature, and incubated for another $30 \mathrm{~min}$ in buffer $(50 \mathrm{mM}$ Tris- $\mathrm{HCl}$ at $\mathrm{pH} 8.3,75 \mathrm{mM} \mathrm{KCl}, 3 \mathrm{mM} \mathrm{MgCl}_{2}$ ). The random ODN library Tag- $\mathrm{N}_{9} \mathrm{X} \bullet \mathrm{Tag}^{\prime}$ and RNase inhibitor were then added

\section{MATERIALS AND METHODS}

\section{Cell culture}

Mouse macrophage cell line RAW264.7 (ATCC) was maintained in Dulbecco's Modified Eagle Medium (DMEM) (Invitrogen) containing $10 \%$ FBS, streptomycin (100 $\mu \mathrm{g} / \mathrm{mL}$ ), and penicillin (100 units $/ \mathrm{mL}$ ) at $37^{\circ} \mathrm{C}$ in a humidified atmosphere incubator with $5 \% \mathrm{CO}_{2}$.

\section{ODNs, ps-ODNs, PNAs, and siRNAs}

ODNs and ps-ODNs were obtained from Integrated DNA Technologies (IDT). The RT-ROL primer, Tag- ${ }_{9} \mathrm{X}, \mathrm{d}(\mathrm{GGATTTGCT}$ GGTGCAGTACANNNNNNNNNX), where $\mathrm{X}$ is $\mathrm{A}, \mathrm{T}, \mathrm{G}$, or $\mathrm{C}$, was synthesized using a mixture of phosphoramidites in a ratio of
TABLE 2. siRNA duplexes for inhibition of iNOS expression

\begin{tabular}{|c|c|c|c|}
\hline siRNA & Site & Sequence $\left(5^{\prime}-3^{\prime} / 3^{\prime}-5^{\prime}\right)$ & Source \\
\hline si-178 & C & $\begin{array}{l}\text { AGUCUCAGACAUGGCUUGCuU } \\
\text { UUUCAGAGUCUGUACCGAACG }\end{array}$ & Start Codon \\
\hline si-178S & $\mathrm{C}$ & $\begin{array}{l}\text { GGCAAUUCCGGACUGCUUCuU } \\
\text { uUCCGUUAAGGCCUGACGAAG }\end{array}$ & Scrambled \\
\hline si-303 & F/G & $\begin{array}{l}\text { CAAUACAAGAUGACCCUAAuU } \\
\text { UUGUUAUGUUCUACUGGGAUU }\end{array}$ & MASL \\
\hline si-481 & $\mathrm{I} / \mathrm{J}$ & $\begin{array}{l}\text { GGCCACAUCGGAUUUCACUuu } \\
\text { UUCCGGUGUAGCCUAAAGUGA }\end{array}$ & MASL \\
\hline si-541 & K & $\begin{array}{l}\text { GAGUUUGACCAGAGGACCCuU } \\
\text { UUCUCAAACUGGUCUCCUGGG }\end{array}$ & Beeharry et al. (2004) \\
\hline si-3957 & & $\begin{array}{l}\text { UACUUAGCUGCACUAUGUAuU } \\
\text { UUAUGAAUCGACGUGAUACAU }\end{array}$ & MASL \\
\hline
\end{tabular}

Top strand is the sense strand, and bottom strand is the antisense strand. 5'-Dangling U's in the antisense strand are complementary to the mRNA. 
TABLE 3. PNAs sequences and their characterization by MALDI

\begin{tabular}{|c|c|c|c|c|c|}
\hline PNA & Site & sequence $\left(\mathrm{NH}_{2} \rightarrow \mathrm{CONH}_{2}\right)$ & $\begin{array}{l}\text { Calculated } \\
\text { Average } \\
(M+1) \text { ion }\end{array}$ & $\begin{array}{l}\text { Observed } \\
(M+1) \text { ion }\end{array}$ & Source \\
\hline PNA-242 & $\mathrm{D}$ & TGTCCTTTTCCTCTTTCA-Lys & 4883.7 & 4879.3 & $\mathrm{MASL}^{\mathrm{a}}$ \\
\hline PNA-264 & $\mathrm{E}$ & GTTTTCTTCACGTTGTTG-Lys ${ }_{4}$ & 5388.3 & 5389.8 & MASL \\
\hline PNA-301 & F/G & GTCATCTTGTATTGTTGG-Lys ${ }_{4}$ & 5437.3 & 5432.5 & MASL \\
\hline PNA-485 & $\mathrm{l} / \mathrm{J}$ & TGAAATCCGATGTGG-Lys 4 & 4656.6 & 4660.2 & MASL \\
\hline
\end{tabular}

${ }^{a}$ Giovine et al. (1998) and Chiarantini et al. (2002).

and incubated for $30 \mathrm{~min}$ before adding SuperScript II Reverse Transcriptase (Invitrogen Life Technologies) for another $5 \mathrm{~min}$. The reaction was then incubated for $50 \mathrm{~min}$ at $42^{\circ} \mathrm{C}$ and inactivated by heating for $15 \mathrm{~min}$ at $70^{\circ} \mathrm{C} .5^{\prime}-\left[{ }^{32} \mathrm{P}\right]$-End labeled ODN Tag d $\left({ }^{32}\right.$ pGGATTTGCTGGTGCAGTACA $)$ was used as the reverse PCR primer, with each of 26 forward PCR primers for mouse iNOS (see Supplemental Table 1). The PCR was carried out with GoTaq polymerase (Promega) for $2 \mathrm{~min}$ at $95^{\circ} \mathrm{C}$, followed by 26 cycles of PCR $\left(30 \mathrm{sec}\right.$ at $95^{\circ} \mathrm{C}, 30 \mathrm{sec}$ at $55^{\circ} \mathrm{C}$, and $30 \mathrm{sec}$ at $72^{\circ} \mathrm{C}$ ). The products were then separated on $8 \%$ denaturing polyacrylamide gels.

\section{Griess assay of iNOS inhibition by ps-ODN, PNA.ODN, or SIRNA}

Mouse peritoneal macrophage RAW264.7 (ATCC TIB-71) cells were maintained in DMEM containing 10\% FBS, streptomycin $(100 \mu \mathrm{g} / \mathrm{mL})$, and penicillin (100 units $/ \mathrm{mL})$ at $37^{\circ} \mathrm{C}$ in a humidified incubator with 5\% $\mathrm{CO}_{2}$. RAW264.7 cells were seeded in 24well plates with $1 \times 10^{5}$ per well in $600 \mu \mathrm{L}$ DMEM with $10 \%$ FBS and incubated for $24 \mathrm{~h}$. The cells were then washed three times with PBS, after which $400 \mu \mathrm{L}$ DMEM (no FBS) and $100 \mu \mathrm{L}$ optiMEM (Invitrogen) were added with Oligofectamine $2000(2 \mu \mathrm{L})$ ps-ODN complex, Lipofectamine 2000 PNA•ODN complex, or Lipofectamine 2000 siRNA complex. Six hours later, LPS (Lipopolysaccharides from Escherichia coli 055:B5, Sigma, $1 \mu \mathrm{g} / \mathrm{mL}$ ), IFN- $\gamma$ (mouse, recombinant, E. coli, Calbiochem, $100 \mathrm{ng} / \mathrm{mL}$; LPS), and $60 \mu \mathrm{L}$ FBS were added with DMEM to make a total of $600 \mu \mathrm{L}$ and further incubated. After an additional $18 \mathrm{~h}$, an aliquot of the supernatant $(50 \mu \mathrm{L})$ was removed for assay of NO by the Griess assay (Promega) and quantified by the absorbance at $540 \mathrm{~nm}$.

\section{Real-time PCR analysis of iNOS mRNA inhibition by siRNAs.}

RNA was extracted using TRIzol Reagent (Invitrogen) according to the manufacturer's instructions and quantified spectrophotometrically. Approximately $5 \mu \mathrm{g}$ of total RNA was treated with TURBO DNase (Ambion) and reverse transcribed with Superscript II Reverse Transcriptase (Invitrogen) and 500 ng of random hexamer (Invitrogen) in a $20 \mu \mathrm{L}$ reaction volume, according to standard protocols supplied by the manufacturer. cDNA synthesis was performed for $50 \mathrm{~min}$ at $42^{\circ} \mathrm{C}$, followed by heat inactivation for $10 \mathrm{~min}$ at $70^{\circ} \mathrm{C}$. The real-time PCR assay was performed using the Applied Biosystems 7500 Fast Real-Time PCR System (Applied Biosystems) with the following profile: 40 cycles of $95^{\circ} \mathrm{C}$ for $3 \mathrm{sec}$ and $60^{\circ} \mathrm{C}$ for $30 \mathrm{sec}$. PCR reactions were carried out in a reaction mixture consisting of $10 \mu \mathrm{L}$ Fast SYBR Green Master Mix $(2 \times)$ with AmpliTaq Fast DNA Polymerase, $200 \mathrm{nM}$ primers, cDNA, and water; the final reaction volume was $20 \mu \mathrm{L}$. The primers used to amplify iNOS were d(TGGTGGTGACAAGCACA TTT) and d(AAGGCCAAACACAGCATACC), and for GAPDH they were d(TGGAGAAACCTGCCAAGTATG) and d(GTTGAAG TCGCAGGAGACAAC). The threshold cycle $\left(\mathrm{C}_{\mathrm{T}}\right)$ was calculated by the instrument's software (7500 Fast System). The relative expression of each mRNA was calculated by the comparative $\mathrm{C}_{\mathrm{T}}$ method $\left(\Delta \Delta \mathrm{C}_{\mathrm{T}}\right)$.

\section{SUPPLEMENTAL MATERIAL}

Supplemental material can be found at http://www.rnajournal.org.

\section{ACKNOWLEDGMENTS}

We thank the National Heart Lung and Blood Institute of the National Institutes of Health as a Program of Excellence in Nanotechnology (NHLBI-PEN HL080729) for support. We also thank Steven L. Brody and Yingiian You of the Washington University School of Medicine for providing help with real-time PCR. We also thank Washington University Siteman Cancer Center for sharing resources and providing technical support.

Received September 28, 2009; accepted April 1, 2010.

\section{REFERENCES}

Allawi HT, Dong F, Ip HS, Neri BP, Lyamichev VI. 2001. Mapping of RNA accessible sites by extension of random oligonucleotide libraries with reverse transcriptase. RNA 7: 314-327.

Arima H, Sakamoto T, Aramaki Y, Ishidate K, Tsuchiya S. 1997. Specific inhibition of nitric oxide production in macrophages by phosphorothioate antisense oligonucleotides. J Pharm Sci 86: 1079-1084.

Beeharry N, Chambers JA, Faragher RG, Garnett KE, Green IC. 2004. Analysis of cytokine-induced NO-dependent apoptosis using RNA interference or inhibition by 1400W. Nitric Oxide 10: 112-118.

Bilecki W, Okruszek A, Przewlocki R. 1997. The effect of antisense oligodeoxynucleotides on nitric oxide secretion from macrophagelike cells. Antisense Nucleic Acid Drug Dev 7: 531-537.

Braasch DA, Corey DR. 2001. Synthesis, analysis, purification, and intracellular delivery of peptide nucleic acids. Methods 23: 97-107.

Braasch DA, Corey DR. 2002. Lipid-mediated introduction of peptide nucleic acids into cells. Methods Mol Biol 208: 211-223.

Chen SJ. 2008. RNA folding: Conformational statistics, folding kinetics, and ion electrostatics. Annu Rev Biophys 37: 197-214.

Chiarantini L, Cerasi A, Fraternale A, Andreoni F, Scari S, Giovine M, Clavarino E, Magnani M. 2002. Inhibition of macrophage iNOS 
by selective targeting of antisense PNA. Biochemistry 41: 84718477.

Chiarantini L, Cerasi A, Fraternale A, Millo E, Benatti U, Sparnacci K, Laus M, Ballestri M, Tondelli L. 2005. Comparison of novel delivery systems for antisense peptide nucleic acids. J Control Release 109: 24-36.

Fang H, Yue X, Li X, Taylor JS. 2005. Identification and characterization of high affinity antisense PNAs for the human unr (upstream of N-ras) mRNA which is uniquely overexpressed in MCF-7 breast cancer cells. Nucleic Acids Res 33: 6700-6711.

Flesch IE, Hess JH, Kaufmann SH. 1994. NADPH diaphorase staining suggests a transient and localized contribution of nitric oxide to host defence against an intracellular pathogen in situ. Int Immunol 6: $1751-1757$.

Giovine M, Gasparini A, Scarfi S, Damonte G, Sturla L, Millo E, Tonetti M, Benatti U. 1998. Synthesis and characterization of a specific peptide nucleic acid that inhibits expression of inducible NO synthase. FEBS Lett 426: 33-36.

Grasso S, Scifo C, Cardile V, Gulino R, Renis M. 2003. Adaptive responses to the stress induced by hyperthermia or hydrogen peroxide in human fibroblasts. Exp Biol Med (Maywood) 228: 491498.

Ho SP, Britton DH, Stone BA, Behrens DL, Leffet LM, Hobbs FW, Miller JA, Trainor GL. 1996. Potent antisense oligonucleotides to the human multidrug resistance- 1 mRNA are rationally selected by mapping RNA-accessible sites with oligonucleotide libraries. Nucleic Acids Res 24: 1901-1907.
Ho SP, Bao Y, Lesher T, Malhotra R, Ma LY, Fluharty SJ, Sakai RR. 1998. Mapping of RNA accessible sites for antisense experiments with oligonucleotide libraries. Nat Biotechnol 16: 59-63.

Kretschmer-Kazemi Far R, Sczakiel G. 2003. The activity of siRNA in mammalian cells is related to structural target accessibility: A comparison with antisense oligonucleotides. Nucleic Acids Res 31: $4417-4424$.

Mukherjee A, Wickstrom E, Thakur ML. 2009. Imaging oncogene expression. Eur J Radiol 70: 265-273.

Nastruzzi C, Cortesi R, Esposito E, Gambari R, Borgatti M, Bianchi N, Feriotto G, Mischiati C. 2000. Liposomes as carriers for DNAPNA hybrids. J Control Release 68: 237-249.

Obernosterer G, Tafer H, Martinez J. 2008. Target site effects in the RNA interference and microRNA pathways. Biochem Soc Trans 36: 1216-1219.

Rodriguez AJ, Condeelis J, Singer RH, Dictenberg JB. 2007. Imaging mRNA movement from transcription sites to translation sites. Semin Cell Dev Biol 18: 202-208.

Sun Y, Duan M, Lin R, Wang D, Li C, Bo X, Wang S. 2006. A novel integrated strategy (full-length gene targeting) for mRNA accessible site tagging combined with microarray hybridization/RNase $\mathrm{H}$ cleavage to screen effective antisense oligonucleotides. Mol Vis 12: 1364-1371.

Zhang HY, Mao J, Zhou D, Xu Y, Thonberg H, Liang Z, Wahlestedt C. 2003. mRNA accessible site tagging (MAST): A novel high throughput method for selecting effective antisense oligonucleotides. Nucleic Acids Res 31: e72. 

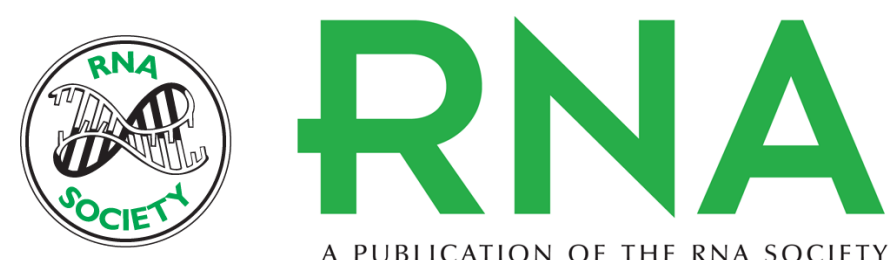

A PUBLICATION OF THE RNA SOCIETY

\section{Native mRNA antisense-accessible sites library for the selection of antisense oligonucleotides, PNAs, and siRNAs}

Huafeng Fang, Yuefei Shen and John-Stephen Taylor

RNA 2010 16: 1429-1435 originally published online May 24, 2010

Access the most recent version at doi:10.1261/rna.1940610

Supplemental
Material http://rnajournal.cshlp.org/content/suppl/2010/05/20/rna.1940610.DC1

References This article cites 22 articles, 1 of which can be accessed free at:

http://rnajournal.cshlp.org/content/16/7/1429.full.html\#ref-list-1

License

Email Alerting Receive free email alerts when new articles cite this article - sign up in the box at the Service top right corner of the article or click here. 